\title{
Investigations on High Performance and Low Emissions GDI Engine used in Agricultural Applications in India
}

\author{
S. P. Chincholkar ${ }^{1}$, Girish Bhiogade ${ }^{2}$, J. G. Suryawanshi ${ }^{3}$ \\ ${ }^{1}$ (Department of Mechanical Engineering, KITS Ramtek, India) \\ ${ }^{2,3}$ (Department of Mechanical Engineering, VNIT Nagpur, India)
}

\begin{abstract}
The present paper describes the modification and conversion of the constant speed DI diesel engine to mechanically operated gasoline direct injection engine (GDI). The gasoline fuel was supplied to the fuel injector by newly developed GDI fuel injection component. Engine head was modified to fix the spark plug and fuel injector at proper position. Compression ratio was changed to operate on GDI mode. Experimental investigations were carried out to optimize the fuel injection and spark ignition timing. Optimized engine achieved low brake specific fuel consumption, maximum in-cylinder pressure, minimum cycle by cycle variations and maximum heat release rate. The study shows optimum compromise between engine performance and emissions was achieved at optimized injection and ignition timings. Study also shows that the engine power was increased by $16.5 \%$ than conventional DI diesel engine. The NOx and smoke emissions from mechanically operated GDI engine were observed to be less comparing to diesel engine used in agricultural applications.
\end{abstract}

Keywords: Compression ratio, Diesel engine, Gasoline direct injection, Port fuel injection, Spark timing.

\section{Introduction}

The worldwide growing concern about environmental degradation and energy security has been added immense pressure on the engine researchers to modify the engine technology which will satisfy future strict emission norms [1,2]. It is tough time for compression ignition (CI) engine to satisfy upcoming emission regulations [3]. Gasoline direct injection engine (GDI) combines the best features of DI diesel and PFI gasoline engine. Theoretically it offers better fuel economy than diesel engines at partial loads and better engine performance than port fuel injection at full load [4,5]. GDI overcomes limitation present in the PFI, it reduces pumping losses, heat losses, cold start problem, carbon dioxide emissions, increases volumetric efficiency and permits to use lower octane fuel [6-8].

Agriculture based countries like India has utilizing 6 millions diesel engine pumps for irrigation purpose and one of the source of pollution in the rural region $[9,10]$. There are promotional schemes from the Indian government for the renewable pump options like solar and wind pumps, but solar pumps due to its low efficiency, high cost, and along with its poor performance on the cloudy day and in the morning and wind pumps due to its high maintenance, depending on wind intensity became the least preferred choice [11]. GDI engine technology can be applied to diesel engine with little modification [12,13].

Many researchers studied the performance of GDI engine with bio-fuels such as ethanol and found satisfactory results without engine modification which can opens a new era for the utilization of bio-fuel in GDI engine and solution to the energy crises and emissions. Stationary application of GDI engine such as in irrigation is rarely studied by the researchers. Here authors converted diesel engine into mechanically operated low cost GDI engine to study its performance and emissions for agricultural applications.

\section{Engine Modifications}

The $5 \mathrm{hp}$, naturally aspirated, water cooled, single cylinder, DI diesel engine modified to run on naturally aspirated GDI engine. The engine specifications of GDI and diesel engines are given in table 1 . Several modifications were done on diesel engine to operate it on GDI mode. The conventional diesel fuel injection system was modified to inject the gasoline fuel directly into the engine cylinder. The electronic ignition system was installed to produce single high intensity spark. The compression ratio of conventional diesel engine was reduced by increasing engine clearance volume because higher compression ratio leads to knocking when the engine operates on GDI mode. Throttle body system which controls the amount of air flow into the cylinder is attached to intake manifold of GDI engine. 
Investigations on High Performance and Low Emissions GDI Engine used in Agricultural ..

Table 1. Engine specifications

\begin{tabular}{|l|l|l|}
\hline Engine & Modified GDI Engine & Diesel Engine \\
\hline Bore & $80 \mathrm{~mm}$ & $80 \mathrm{~mm}$ \\
\hline Stroke & $110 \mathrm{~mm}$ & $110 \mathrm{~mm}$ \\
\hline Displacement & $553 \mathrm{CC}$ & $553 \mathrm{CC}$ \\
\hline Compression ratio & 9.5 & 16.5 \\
\hline No. of valves & 02 & 02 \\
\hline No. of cylinder & 01 & 01 \\
\hline Cooling system & Water cooled & Water cooled \\
\hline Fuel injector & Multihole & Multihole \\
\hline Fuel system & Direct injection & Direct injection \\
\hline Spark ignition system & Electronic ignition & ------ \\
\hline Engine speed (rpm) & 1350 & 1500 \\
\hline
\end{tabular}

\section{A] Spark Ignition System}

The magneto ignition system and contact breaker-cam operated inductive system made bulky assembly on the engine camshaft hence, electronic ignition system is preferred to use as ignition system for GDI engine. It has longer spark and ability to ignite the air fuel mixture over a wider range of engine operation which is more suitable for the GDI engine operation. Commercially available electronic spark ignition system is used in the modified engine. The magnet was fixed on the camshaft and pulser coil mounted on the engine body. The gap between magnet and breaker was maintained between 1.2-1.5 mm. The spark timing was fixed by adjusting the position between magnet and pulser coil along with the position of flywheel with respect to TDC marker on the engine. The system has facility to advanced or retard the spark timing by the interval of $3^{\circ}$ Crank Angle.

\section{B] Engine Head Modification}

Spark plug packaging on the cylinder head is most critical and challenging part due to the limited space available on the cylinder head [14]. The task was accomplished by observing the spray lines and taking engine head cut section to decide the location for the spark plug. Figure 1 shows the spray lines and spark plug position. This was the only position on the cylinder head $37 \mathrm{~mm}$ away from the centre of the head which satisfied all the requirements. The other positions either damaged the water lines or were not meeting the fuel spray lines. A hole was drilled vertically at selected position into the engine head to fit the spark plug. Spark plug is mounted at the edge of bowl in piston and extended into the combustion chamber so that rich combustible air fuel mixture shall be available at the time of the spark. Diesel injector is used to inject the gasoline fuel in GDI engine without any modification.

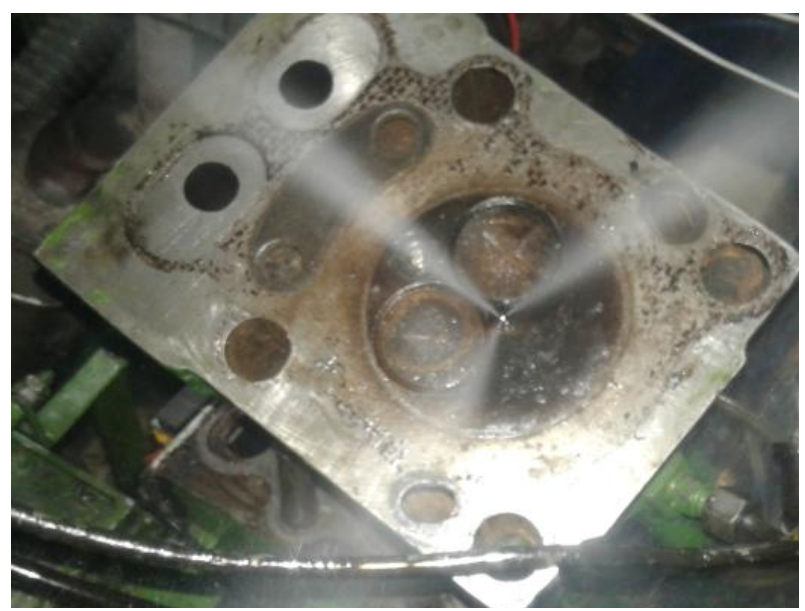

Fig. 1. Spark plug and injector position in cylinder head

\section{C] Development of GDI Fuel Injection Component}

In the present study, GDI fuel injection component was developed and installed on the engine to change the fuel injection timing. The new system is more convenient and did not disturb the engine camshaft. As system mounted outside, it may eliminate the practical difficulty in changing the injection timing which may arise in splined coupling arrangement.

Figure 2 shows the fuel pump position before and after modifications. GDI fuel injection component was developed to change the fuel injection timing. Camshaft motion was transmitted to the GDI pulley in 1:1 ratio. The GDI pulley connected with GDI fuel injection component which has a capability to change injection 
timing. Fuel injection timing was set by adjusting timer pulley with respect to fuel injection timing mark on GDI component and with TDC marker on engine. Ball type governor present in the diesel engine was retained and GDI pump connected with governor by newly developed mechanism. The engine was maintained at constant speed $1350 \mathrm{rpm}$ by controlling fuel supply to the engine. The homogeneous mixture could be obtained by injecting fuel early in the suction stroke while stratified mixture could be obtained by injecting fuel late in the compression stroke. Figure 3 shows the schematic of GDI component. Fuel pump mounted on GDI box and operated by cam shaft. Part 6, 7 and 8 combine act as timer pulley. The injection time is set by adjusting timer pulley with respect to TDC marker on engine.

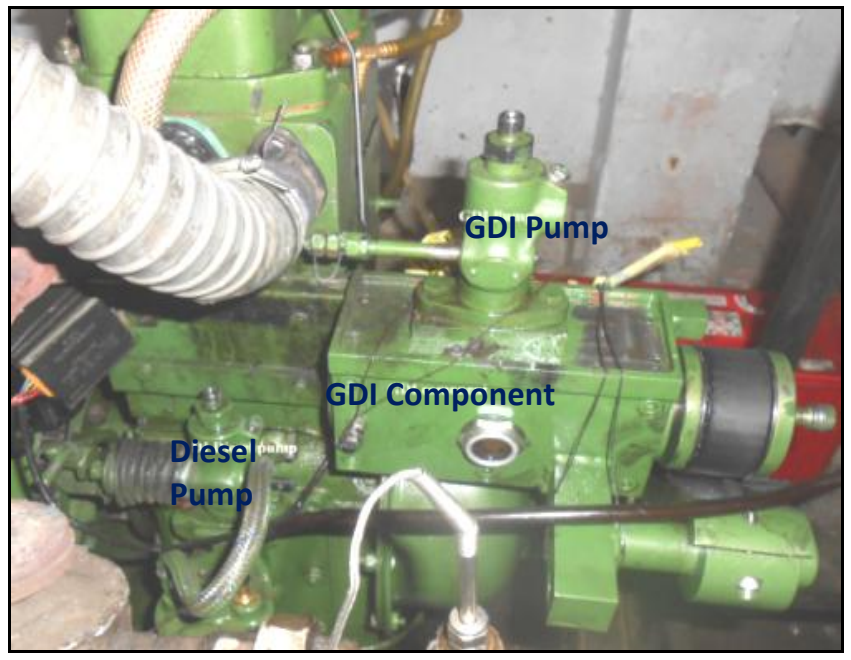

Fig. 2. GDI fuel pump location

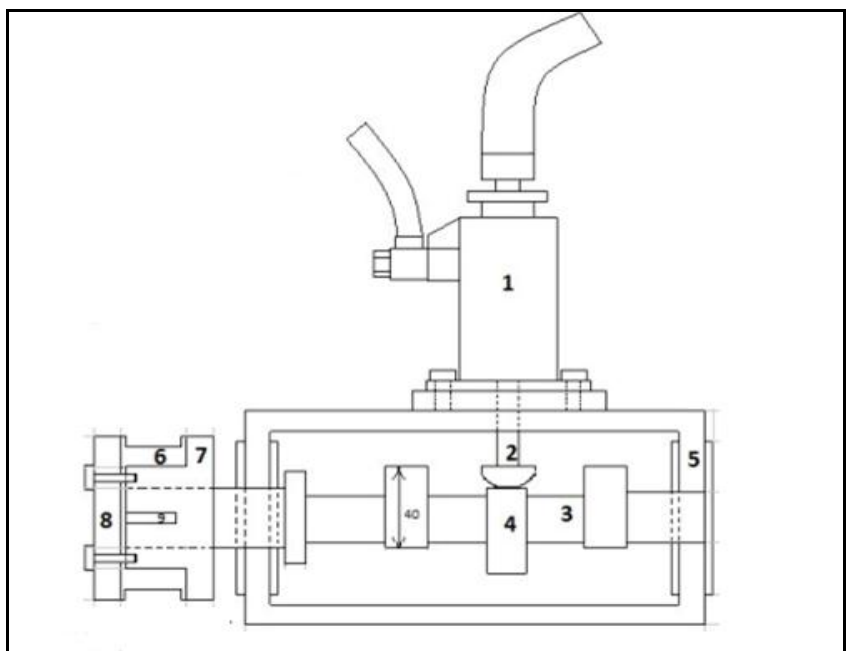

1. Fuel pump 2. Follower 3. Cam shaft 4. Cam 5. GDI box 6. Pulley 7. Flange 8. Cover plate

Fig. 3. GDI fuel injection component

III. Experimental Set - Up

The experiments were carried out on a single-cylinder, four strokes, naturally aspirated, water-cooled, GDI engine which was modified from DI diesel engine. Figure 4 shows schematic GDI engine experimental set up and figure 5 shows actual laboratory set-up of GDI engine. An eddy current dynamometer was directly coupled to the engine output shaft to measure engine torque. Fuel consumption was measured in terms of the volume of gasoline consumed during a specified period of time. In-cylinder pressure was measured using M111A22 quartz crystal dynamic pressure transducer with built in amplifier having $1 \mathrm{mV} / \mathrm{psi}$ sensitivity. The crankshaft position was obtained using an encoder with 1degree resolution to determine the in-cylinder pressure as a function of crank angle. All temperatures were measured with $\mathrm{K}$ type thermocouples. The exhaust emissions were measured with AVL $4000 \mathrm{Di}$ gas analyzer. The detection limits of NOx, HC and CO were 1 ppm, $1 \mathrm{ppm}$ and $0.01 \%$ respectively. The cylinder head was modified to fit the spark plug. A single spark electronic ignition system was used to produce the spark for the gasoline mixture combustion. Spark plug was mounted close to the edge of combustion chamber and extended into the combustion chamber to meet the fuel spray lines sprayed by the fuel injector. 


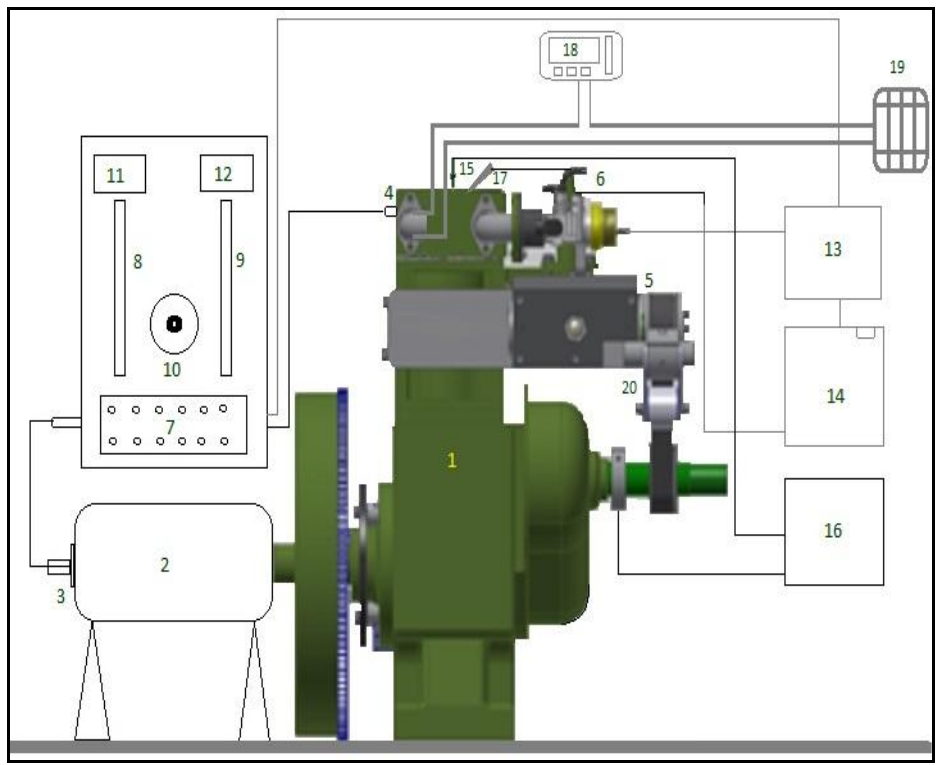

1. Engine 2. Eddy current dynamometer 3. Shaft encoder 4. Pressure transducer 5. DI Fuel injection component 6. Air throttle 7. Data acquisition system 8. Air manometer 9.Fuel manometer 10. Regulator 11. RPM display 12. Temperature display 13. Air tank 14. Fuel tank 15. Spark plug 16. Electronic spark ignition system 17. Fuel injector 18. Gas analyser 19. To exhaust 20.Belt transmission system

Fig. 4. Schematic experimental set-up of GDI engine

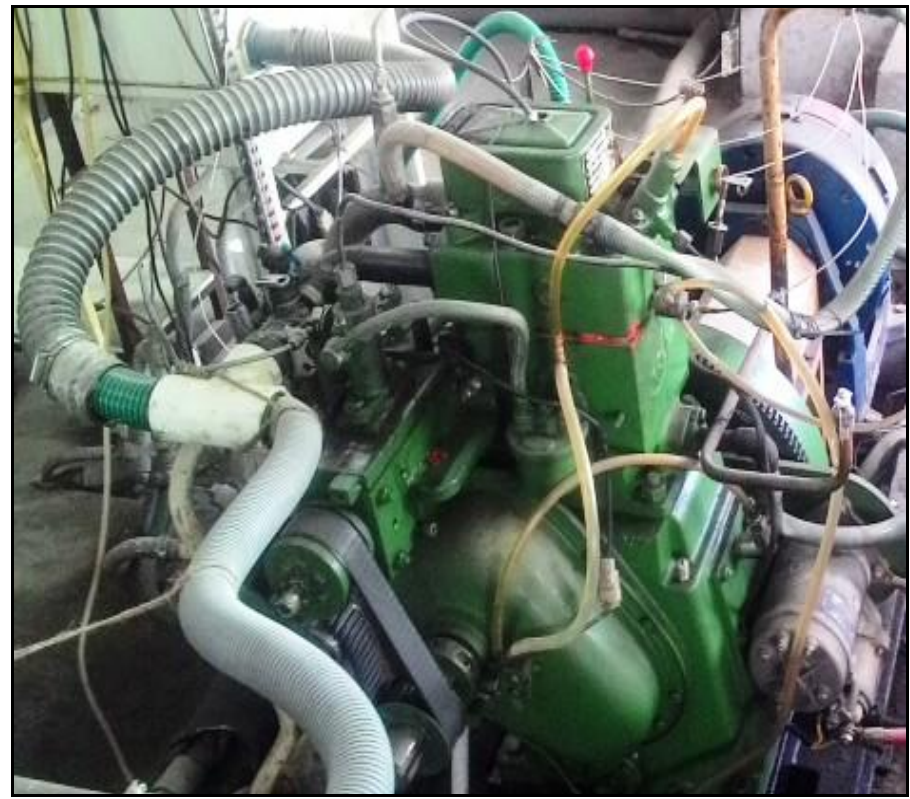

Fig. 5. GDI engine experimental set-up

\section{Results And Discussion}

\section{A] OPTIMIZATION OF SPARK IGNITION AND FUEL INJECTION TIMING}

The fuel injection timing and spark ignition timings were optimized for minimum brake specific fuel consumption. The figure 6 shows the effect of spark timing (ST) on brake specific fuel consumption for given fuel injection timings (FI). The minimum BSFC was found at fuel injection of 45 degree CA bTDC and spark timing of 20 degree CA bTDC. This is the only optimum combination at which minimum BSFC was observed. It may be because of ideal combustion condition present at this combination. Figure 7 also shows that minimum BSFC spark timing varies with injection timing. 


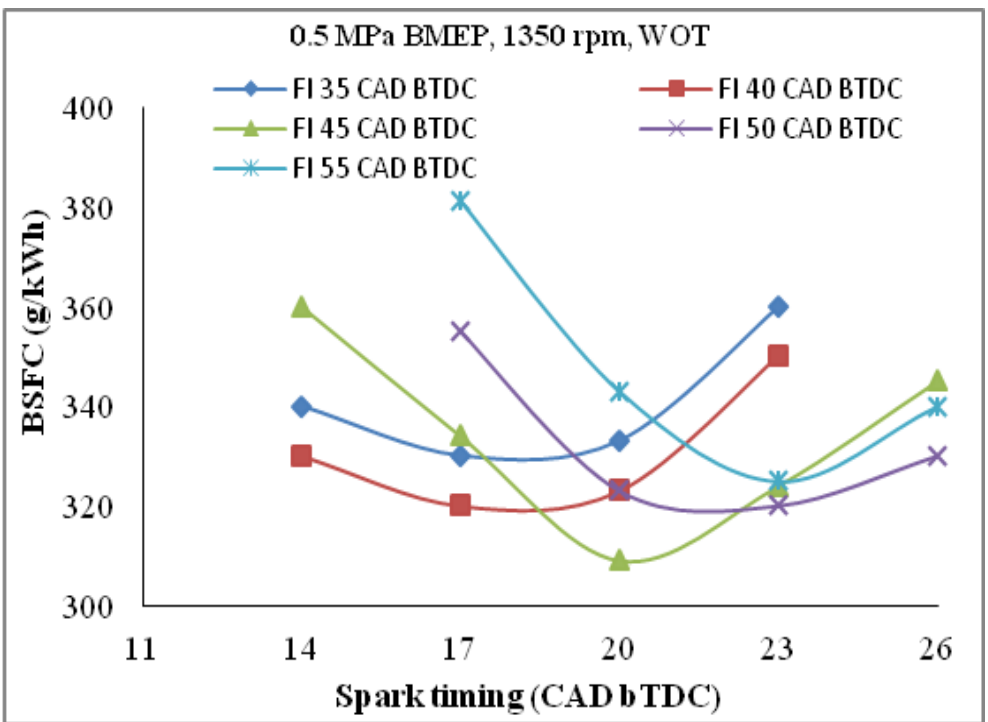

Fig. 6. Effect of spark timing on BSFC at different injection timing

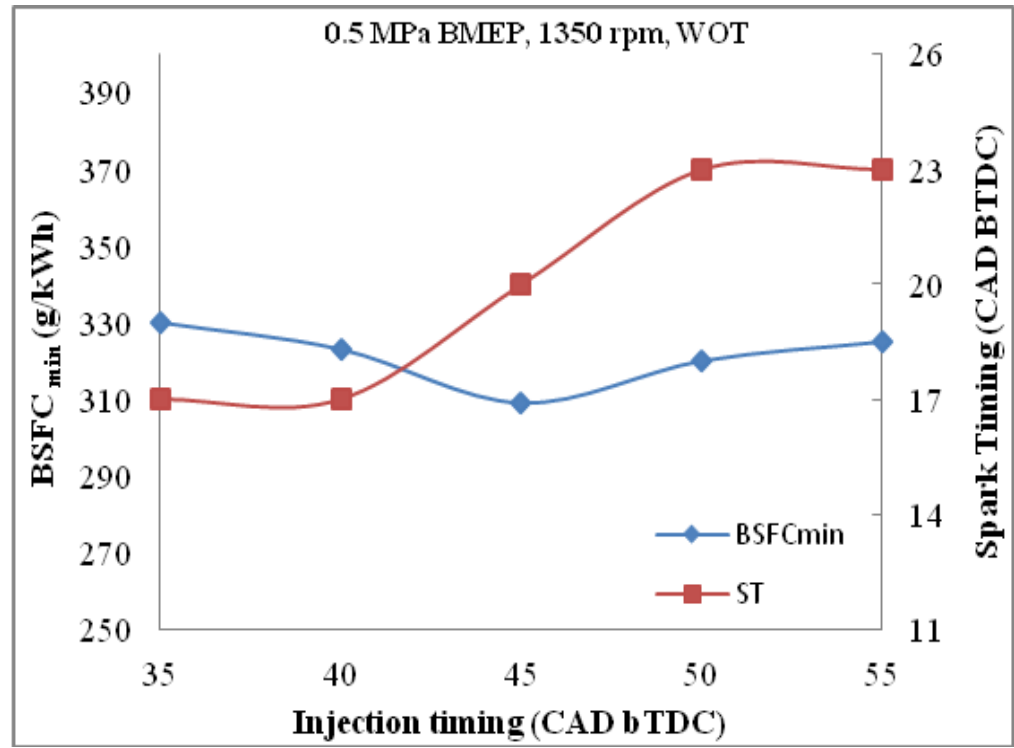

Fig. 7. Effect of injection timing on BSFC at different spark timing

\section{B] EFFECT OF SPARK TIMING ON ENGINE PERFORMANCE AND EMISSIONS}

The effect of spark ignition timing (ST) on brake thermal efficiency (BTE) was studied at an engine speed $1350 \mathrm{rpm}$ and brake mean effective pressure (BMEP) $0.7 \mathrm{MPa}$. Fuel injected at 45 degree CA bTDC and at $20 \mathrm{MPa}$ injection pressure directly into the cylinder. Spark timing changed at an interval of 3degree CA and the tests were carried out at wide open throttle (WOT) condition.

Figure 8 shows the effect of igniton timing on brake thermal efficiency (BTE). The highest value of BTE and lowest coefficient of variation in indicated mean effective pressure $\left(\mathrm{COV}_{\text {imep }}\right)$ were observed at Spark Timing 20 degree CA bTDC. It was due to the correct stratified mixture formation and highest flame speed achieved at Spark Timing 20 degree CA bTDC. The lower BTE and higher $\mathrm{COV}_{\text {imep }}$ were observed for advanced and retarded spark timing. Figure 9 shows the effect of ignition timing on coefficient of variation. The development of unfavourable mixture for ignition and flame propogation near the spark plug due to overmixing and undermixing phenomenon reduces the performance of engine in both cases[16]. 


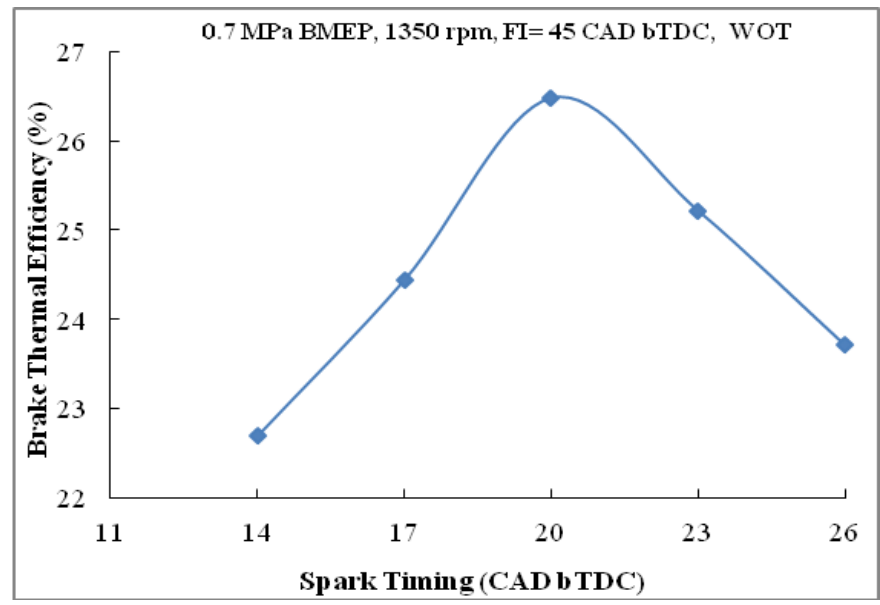

Fig. 8. Effect of spark timing on brake thermal efficiency

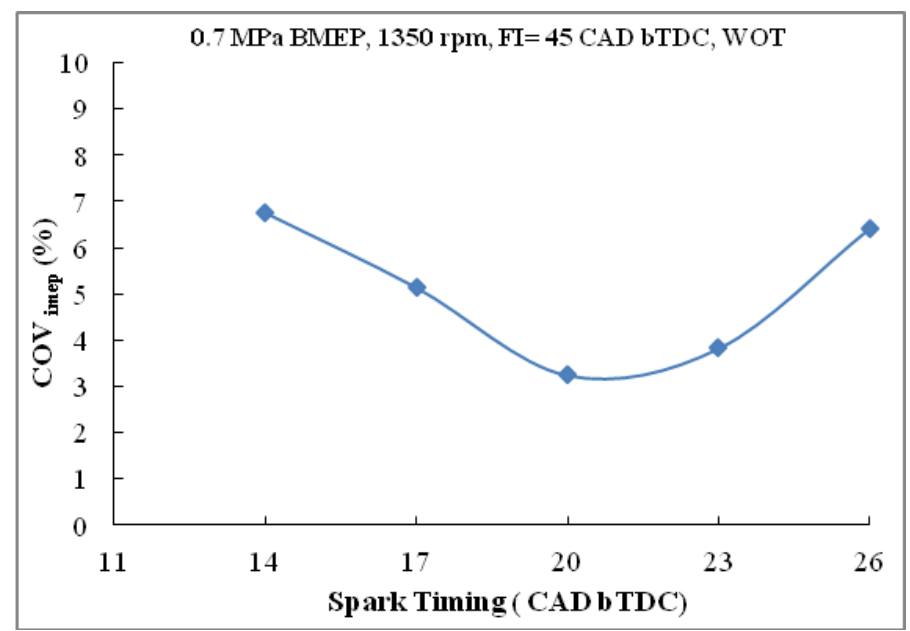

Fig. 9. Effect of spark timing on COV imep

Figure 10 shows the effect of Spark Timing on maximum cylinder pressure. Maximum cylinder pressure $\left(\mathrm{P}_{\max }\right)$ and maximum heat release rate $\left(\mathrm{HRR}_{\max }\right)$ achieved at Spark Timing 20 degree CA bTDC. Retarded spark timing reduces $\mathrm{P}_{\max }$ and $\mathrm{HRR}_{\max }$ and their position being shifted away from the TDC. In advance spark timing the work transfer from the piston on the gas is greater hence thereby increasing negative work. In retarded spark timing the work transfer by the gases on the piston is comparatively less. Figure 11 shows the effect of Spark Timing on maximum heat release rate.

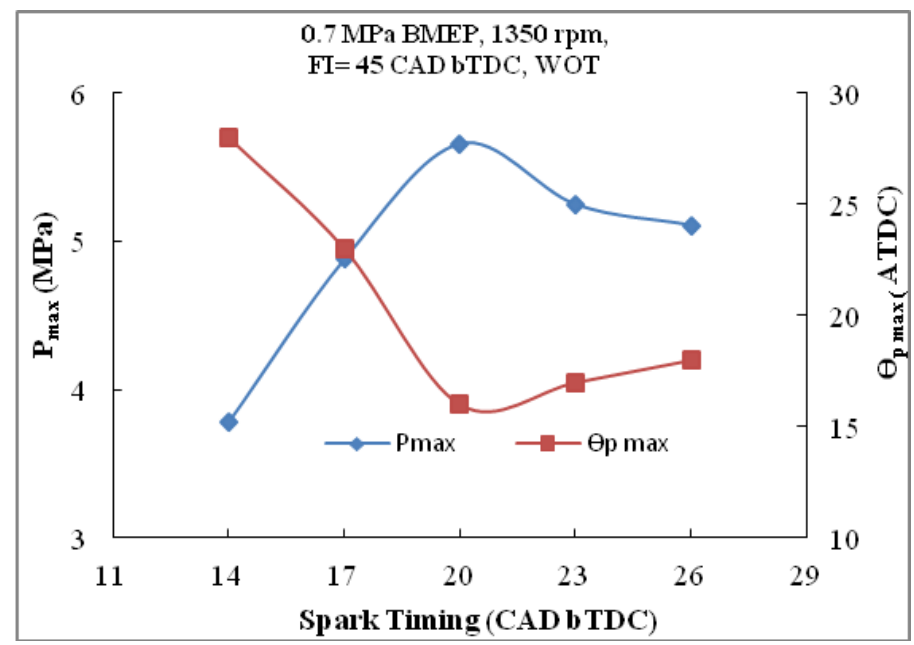

Fig. 10. Effect of spark timing on cylinder pressure 


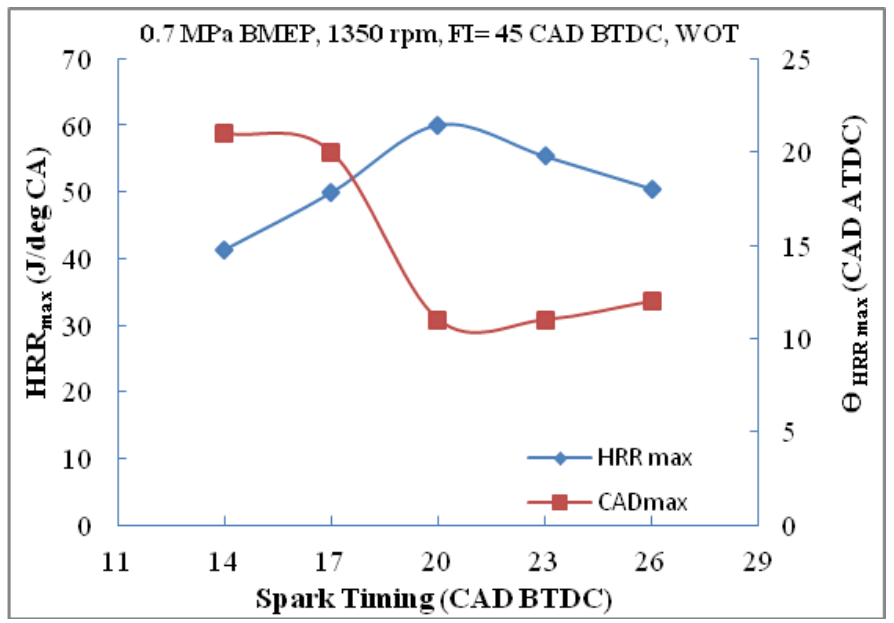

Fig. 11. Effect of spark timing on heat release rate

Figure 12, 13 and 14 shows the effect of spark ignition timing on engine exhaust emissions. $\mathrm{NO}_{\mathrm{x}}$ emission increases with advancing Spark Timing. High peak pressure was observed for slight advanced Spark Timing which indicates higher combustion temperature hence, higher $\mathrm{NO}_{\mathrm{x}}$ emissions [17]. The $\mathrm{HC}$ emission increases and $\mathrm{CO}$ emission decreases with retarded spark timing and vice versa with advance spark timing. With retarded spark timing more time is available for combustion thereby increases the $\mathrm{HC}$ emissions due to homogeneity and flame quenching. The $\mathrm{CO}$ emission decreases with retarded spark timing because of enough oxygen availability for combustion. The Spark Timing 20 degree CA bTDC at optimized Fuel Injection timing shows highest thermal efficiency. This is the optimum compromise between $\mathrm{BTE}, \mathrm{NO}_{\mathrm{x}}, \mathrm{HC}$ and $\mathrm{CO}$ emissions for a GDI engine.

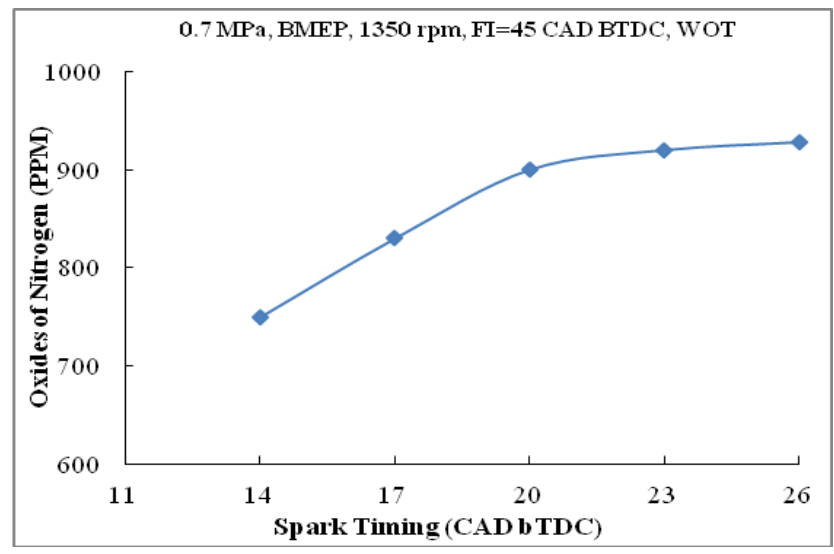

Fig. 12. Effect of spark timing on NOx emission

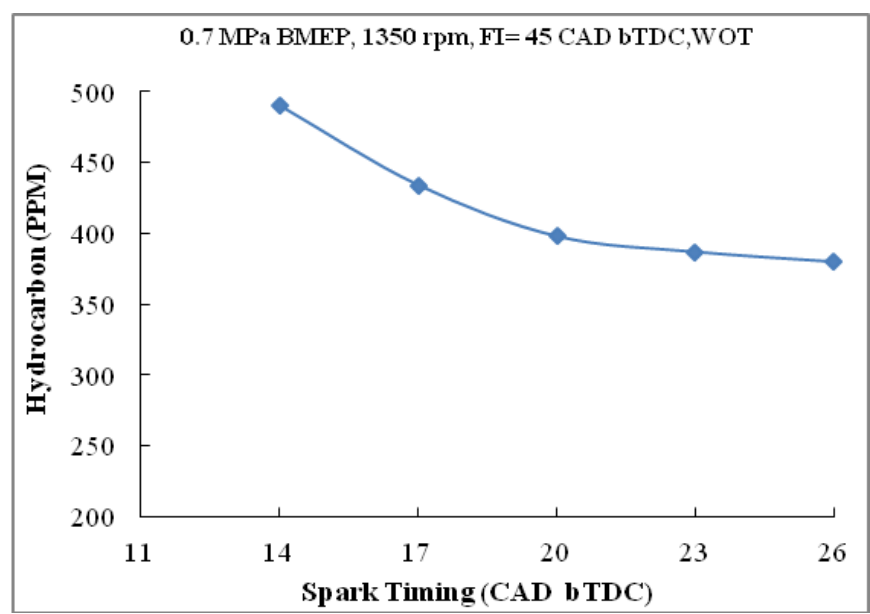

Fig. 13. Effect of spark timing on $\mathrm{HC}$ emission 


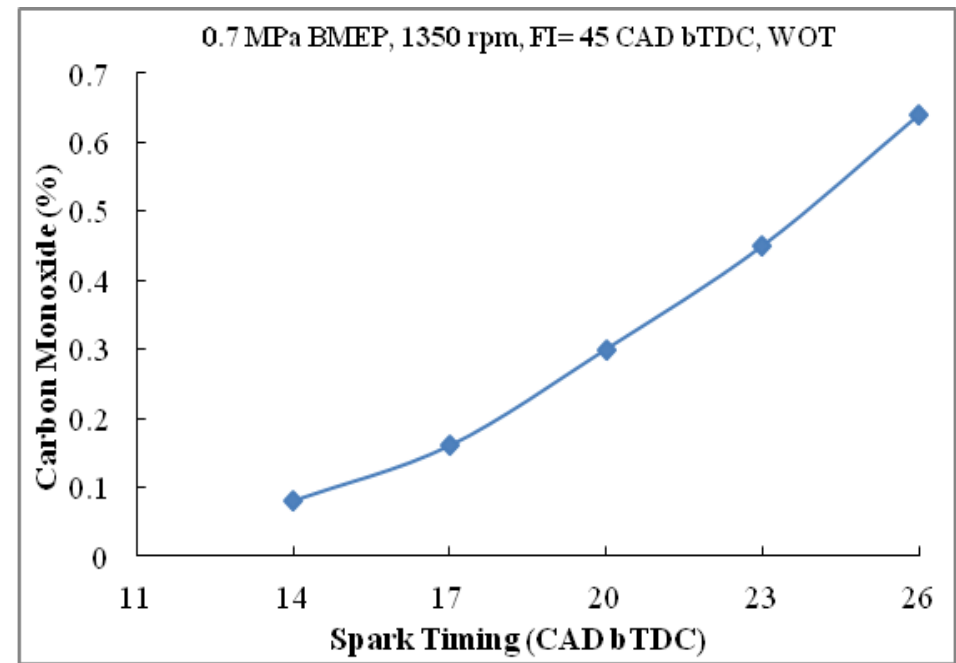

Fig. 14. Effect of spark timing on $\mathrm{CO}$ emission

\section{Comparison Between Carburetor Engine, Diesel Engine And GDI Engine}

The investigations were carried out to compare the optimized GDI performance and emissions with carburetor and diesel mode. The carburetor was fitted with intake manifold to take test data at $1350 \mathrm{rpm}$ by adjusting throttle position. The Spark Timing was optimized for carburetor mode and tests were taken at full load. The GDI emissions are compared with diesel and carburetor mode at $1350 \mathrm{rpm}$ and $5 \mathrm{bar}$ BMEP in figure 15,16 and 17. It is observed that CO emissions decreased significantly by $88 \%$ and $84 \%$ as compared to diesel and carburetor mode. Hydrocarbon emissions produced lesser than carburetor and equivalent to diesel in GDI mode. This indicates the better combustion in GDI mode than other two modes. $\mathrm{NO}_{\mathrm{x}}$ emissions are slightly lesser than diesel may be due to higher latent heat of vaporization of gasoline fuel and lower compression ratio in the GDI mode than diesel mode.

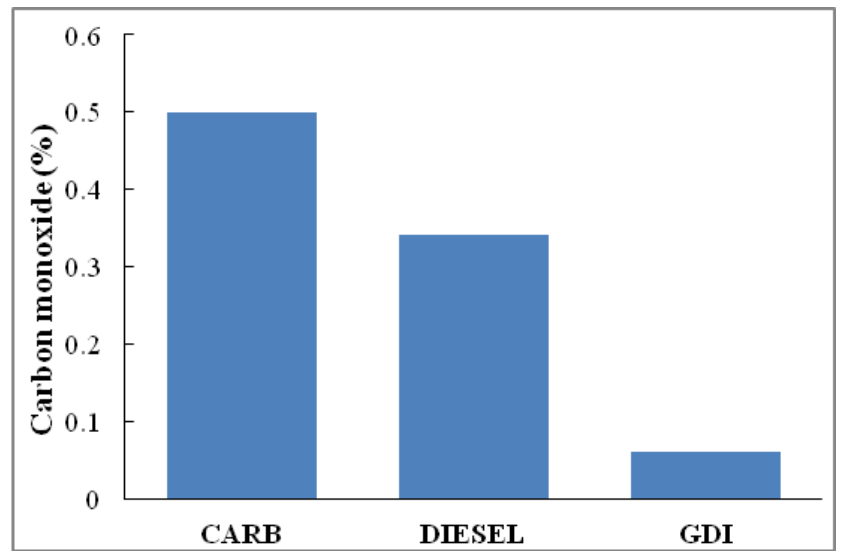

Fig. 15. Comparison of $\mathrm{CO}$ emissions at 5 bar BMEP

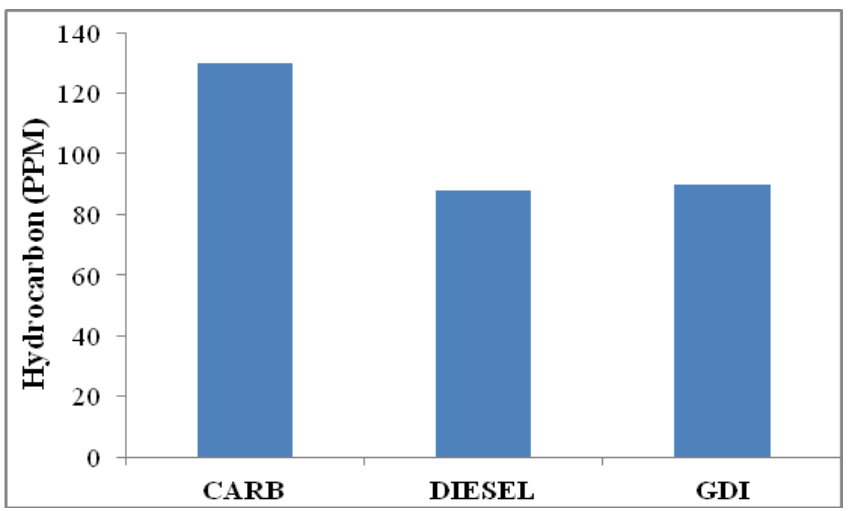

Fig. 16. Comparison of $\mathrm{HC}$ emission at 5 bar BMEP 


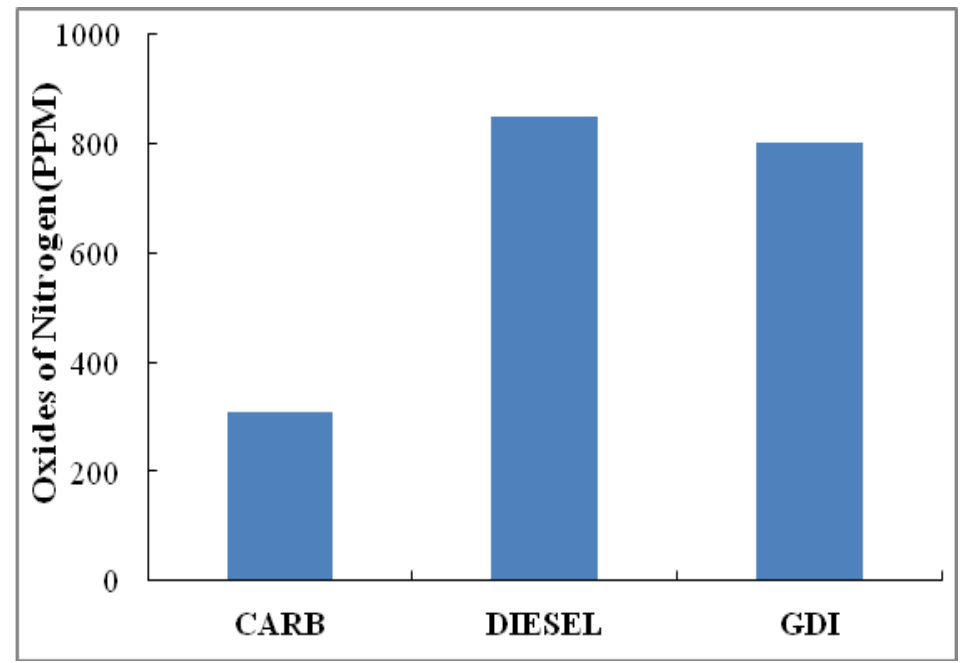

Fig. 17. Comparison of NOx emission at 5 bar BMEP

\section{Conclusions}

1. The DI constant speed diesel engine is modified to operate on GDI mode by using developed GDI fuel injection component, cylinder head modification and electronic ignition system.

2. The ignition timing, fuel injection timing and fuel injection pressure significantly affects the GDI engine performance and emissions and have optimize timing at which it gives optimum performance. Higher injection pressure gives better performance and lesser emissions. Optimized condition is the good compromise between BTE and emissions like $\mathrm{NO}_{\mathrm{x}}, \mathrm{HC}$ and $\mathrm{CO}$.

3. The modified GDI engine produced maximum BTE (26.47\%), lesser $\operatorname{COV}_{\text {imep }}$ (3.24\%), maximum incylinder pressure $(5.68 \mathrm{MPa})$ and maximum heat release rate $\left(60.04 \mathrm{~J} /{ }^{\circ} \mathrm{CA}\right)$ at optimized fuel injection and ignition timings and their location were nearest to the TDC.

4. The developed GDI engine produces $16.5 \%$ and $38.7 \%$ more power than diesel and carburettor mode respectively. CO emissions are reduced by 88 and $84 \%$ in GDI mode as compared to diesel and Carburettor mode, Lesser $\mathrm{NO}_{\mathrm{x}}$ emissions and diesel equivalent $\mathrm{HC}$ emissions were found in GDI mode running at $1350 \mathrm{rpm}$ and $0.5 \mathrm{MPa}$ BMEP.

$\begin{array}{ll}\text { BSFC } & \text { : Brake specific fuel consumption } \\ \text { BMEP } & \text { : Brake mean effective pressure } \\ \text { bTDC } & : \text { Before top dead centre } \\ \text { aTDC } & : \text { After top dead centre } \\ \text { DI } & : \text { Direct injection } \\ \text { FI } & : \text { Fuel injection } \\ \text { GDI } & : \text { Gasoline direct injection } \\ \text { HC } & : \text { Hydrocarbon } \\ \text { NOx } & \text { : Nitric Oxide } \\ \text { rpm } & : \text { Rotation per minute } \\ \text { ST } & : \text { Spark timing } \\ \text { TDC } & : \text { Top dead centre } \\ \text { WOT } & : \text { Wide open throttle. }\end{array}$

\section{NOMENCLATURE}

\section{References}

[1]. M. Costa, U. Sorge, and L. Allocca, CFD optimization for GDI spray model tuning and enhancement of engine performance, Advances in Engineering Software, 49 (2012) Pages 43-53.

[2]. M. Drake and D. Haworth, Advanced gasoline engine development using optical diagnostics and numerical modeling, Proceedings of the Combustion Institute, 31 (2007) Pages 99-124.

[3]. J. Lujan, H. Climent, R. Novella and M. Perea, Influence of a low pressure EGR loop on a gasoline turbocharged direct injection engine, Applied Thermal Engineering 89 (2015) Pages 432-443.

[4]. F. Zhao, M. C. Lai and D. L. Harrington, Automotive spark-ignited direct-injection gasoline engines, Progress in Energy and Combustion Science, 25 (1999) Pages 437-562.

[5]. T. Kume, Y. lwamoto, K. lida, M. Murakami, K. Akishino, and H. Ando, Combustion Control Technologies for Direct Injection SI Engine. SAE Paper 960600.

[6]. S. Kono, Study of the stratified charge and stable combustion in DI Gasoline engine, JSAE review, 16(1995) Pages 363-368. 
[7]. J. Harada,T. Tomita, H. Mizano, Z. Mhashiki and Y. Ito, Development of gasoline direct injection system. SAE Paper 970540.

[8]. R. Rotondi and G. Bella, Gasoline direct injection spray simulation, International J Thermal Sciences, 45(2006)Pages 168-179.

[9]. S. Chandel, M. Naik and R. Chandel, Review of solar photovoltaic water pumping system technology for irrigation and community drinking water supplies, Renewable and Sustainable Energy Reviews,49(2015)Pages 1084-1099.

[10]. C. Gopal, M. Mohanraj, P. Chandramohan, and P. Chandrasekar, Renewable energy source water pumping systems-A literature review, Renewable and Sustainable Energy Reviews 25( 2013) 351-370.

[11]. R. Pelt, C. Weiner and R. Waskom, Solar-powered Groundwater Pumping Systems, Colorado state university extension, 1/08 revised $8 / 2012$.

[12]. J. Li, J. Chae, K. Zeng, S. Lee, Y. Jeong, J. Noh and M. Cho, Preliminary Investigation of A Diffusing-Oriented Spray Stratified Combustion System for DI Gasoline Engines, SAE Paper 980151.

[13]. J. Li, Chang-Ming Gong,Y. Su, H. Dou, and X. Liu, Effect of injection and ignition timings on performance and emissions from a spark-ignition engine fueled with methanol, Fuel. 89 (2010) Pages 3919-3925.

[14]. N. Jackson, J. Stokes, P. Whitaker and T. Lake, Stratified and homogeneous charge operation for the direct injection gasoline engine- high power with low fuel consumption and emissions, SAE Paper 970543

[15]. J. Song, T. Kim, J. Jang and S. Park, Effects of the injection strategy on the mixture formation and Combustion characteristics in a DISI (direct injection spark ignition) optical engine, Energy 93 (2015) Pages 1758 to1768.

[16]. C. Park, S. Kim, H. Kim, Y. and Moriyoshi, Stratified lean combustion characteristics of a spray-guided combustion system in a gasoline direct injection engine, Energy 41 (2012) Pages 401 to 407.

[17]. J. Heywood, Internal combustion engine fundamentals, McGraw-Hill Education, Singapore, 1988.

[18]. H. Oh and C. Bae, Effects of the injection timing on spray and combustion characteristics in a spray-guided DISI engine under leanstratified operation, Fuel 107 (2013) 225-235. 